DOI 10.15290/cnisk.2021.01.10.14

JUSTYNA ZAJKO-CZOCHAŃSKA

https://orcid.org/0000-0001-6414-8280

Uniwersytet w Białymstoku

\title{
Działalność naukowa i upowszechniająca badania naukowe Ośrodka Badań Historii Kobiet Instytutu Studiów Kobiecych w 2020 r. ${ }^{1}$
}

W 2020 r. zespół badawczy Ośrodka Badań Historii Kobiet Instytutu Studiów Kobiecych kontynuował cykliczne spotkania zainicjowane w 2019 r. W ramach realizowanego projektu kontynuowano badania nad historia kobiet, $\mathrm{w}$ tym wizerunkiem prezentowanym w opinii publicznej i mediach, zwłaszcza w prasie XIX i XX w.

Jednym $z$ głównych celów Ośrodka jest organizacja spotkań naukowych, w ramach których przedstawiane sa wyniki prowadzonych badań naukowych. Pierwsze spotkanie odbyło się 7-8 lutego 2020 r. przy współpracy Zakładu Historii Kultury, Myśli i Ruchów Społecznych UwB, któremu przewodzi prof. dr hab. Małgorzata Dajnowicz. Obrady toczyły się głównie wokół tematyki źródeł i metod badań historii kobiet. Spotkanie zainaugurowała prof. dr hab. Małgorzata Dajnowicz, witajac oraz przedstawiajac zgromadzonych uczestników. Profesor przypomniała także obecnym o celu działalności Ośrodka Badań Historii Kobiet w 2019 r. Jako kolejna głos zabrała dziekan Wydziału Historii i Stosunków Międzynarodowych

\footnotetext{
Sprawozdanie przygotowane/finansowane w ramach programu Ministra Nauki i Szkolnictwa Wyższego pod nazwa DIALOG w latach 2019-2021. Jest wynikiem udziału w projekcie badawczym pt. „Ośrodek badań historii kobiet”, nr 0016/DLG/2019/10.
} 
Uniwersytetu w Białymstoku dr hab. Joanna Sadowska, prof. UwB, gratulując przedsięwzięcia oraz wyrażając zadowolenie $z$ charakteru spotkania naukowego.

Obrady merytoryczne rozpoczęło wystapienie prof. dr hab. Jolanty Chwastyk-Kowalczyk, która zaprezentowała periodyk „Nowy Czas” oraz przykład dziennikarki emigracyjnej Teresy Bazarnik-Małkiewicz, podejmującej inicjatywy kulturalno-społeczne, do których angażowała rzeszę Polaków w Londynie. Drugi referat wygłosiła dr Anna Szwed-Walczak, w którym przedstawiła wyniki z badań nad wywiadami prasowymi o charakterze społeczno-politycznym, ukazującymi się w polskiej prasie kobiecej w latach 1989-1992. Autorka wystapienia poddała analizie czasopisma o nakładzie powyżej 500 tys. egzemplarzy, tj. „Przyjaciółkę” oraz „Kobietę i Życie”. Z badań wynikał wniosek, że na łamach „Kobiety i Życia” przeważały wywiady na temat równości płci w polityce, najmniej zaś traktowało o pomocy społecznej. W przypadku „Przyjaciółki” wywiady na oba tematy były przeprowadzane $\mathrm{w}$ równym stopniu. Kolejne wystapienie dotyczyło źródłowego badania nad Polską Kroniką Filmowa rozpowszechniana w latach 1944-1994. Doktor Łukasz Jędrzejski zaprezentował sylwetkę Heleny Lemańskiej - redaktor naczelnej Kroniki. Następnie głos zabrały dr Urszula Sokołowska oraz mgr Justyna Zajko-Czochańska, które skoncentrowały się na specyficznym materiale źródłowym, jakim jest list do redakcji (na przykładzie „Przyjaciółki” oraz „Kobiety i Życia”). Prelegentki zaakcentowały autentyczność źródła oraz opowiedziały o podejmowanych przez autorki listów tematach i problemach w okresie PRL. Druga część obrad rozpoczęła dr hab. prof. USz Agnieszka Szudarek, prezentując Przydatność akt pruskiej administracji państwowej i samorzadowej $w$ badaniach nad organizacjami kobiecymi $w$ miastach zaboru pruskiego na przełomie XIX $i$ XX wieku. Wystapienie na temat lwowskich źródeł do historii kobiet przygotowała dr hab. prof. UJK Lidia Michalska-Bracha. Prelegentka przedstawiła dokumentację Zjednoczenia Polskich Chrześcijańskich Towarzystw Kobiecych w latach 1913-1939 na przykładzie Eleonory Lubomirskiej czy Antoniny Marczyńskiej. Przy temacie lwowskich archiwów pozostawał referat mgr Katarzyny Świetlik pt. Lwowska spuścizna Zofii Romanowiczówny (1842-1936). Ostatnie wystapienie pierwszego dnia obrad należało do mgr. Pawła Wosia - nakreślił on wizerunek Marii Wysłouchowej, działającej w Galicji, która w swo- 
jej działalności kulturowej inspirowała się powieścią Marta Elizy Orzeszkowej.

Na zakończenie pierwszego dnia obrad prof. dr hab. Małgorzata Dajnowicz zapoznała uczestników z planami Ośrodka Badań Historii Kobiet na rok 2020. Zapowiedziała m.in. konferencję pt. Ruchy kobiece na ziemiach polskich. Stan badan i perspektywy (na tle porównawczym), która zaplanowano w terminie 15-17 maja 2020 r. Poddała rozwadze termin szkoły letniej organizowanej w lipcu 2020 r. Ponadto wyznaczono termin złożenia tekstów artykułów do planowanej pokonferencyjnej monografii książkowej.

Drugi dzień obrad moderował dr hab. prof. UwB Adam Miodowski, a rozpoczęto go referatem $z$ epoki średniowiecza. Doktor hab. prof. UwB Robert Suski zaprezentował opracowanie pt. Amazonki $w$ „Historii adversus paganos” Orozjusza. Dzieje recepcji i reinterpretacji mitu. Jako kolejna głos zabrała mgr Magdalena Gąsowska, prezentując referat pt. Kobieca asceza $w$ niemieckim pietyzmie na przełomie XVII i XVIII wieku. Listy Wiary jako źródło do badania dziejów religijności kobiet. Odmienną tematykę podjęła prof. dr hab. Katarzyna Laskowska, która skoncentrowała się na specyfice karania kobiet oraz na odpowiedzialności sprawców za przestępstwa wobec kobiet w Rosji. Doktor Maria Bauchrowicz-Tocka zaprezentowała wyniki badan dokumentów osobistych, takich jak listy, sprawozdania, noty biograficzne itp. traktujace o członkiniach Ligi Kobiet. Referentka wykazała, że dokumenty osobiste w znaczny sposób wzbogacaja i uzupełniaja informacje o działalności Ligi Kobiet. Kolejny referat wygłosiła dr Anna Marcinkiewicz-Kaczmarczyk, przedstawiając historie kilku postaci - członkin Związku Walki Zbrojnej, a w późniejszym czasie Armii Krajowej. Prelegentka zaprezentowała działalność m.in. Haliny Zakrzewskiej oraz Elżbiety Zawackiej. Jako ostatnia wyniki dociekań naukowych przedstawila mgr Agnieszka Drozdowska, prezentując biuletyn „Nasza Praca". Autorka wystapienia zaznajomiła uczestników z podstawowymi informacjami o czasopiśmie, takimi jak skład redakcyjny, nakład, i jego głównymi tematami, które dotyczyły funkcjonowania i działalności Ligi Kobiet.

Podczas dwudniowych obrad bezpośrednio po każdym wystapieniu merytorycznym uczestnicy spotkania warsztatowego odrębnej analizie poddawali źródła, materiały, na podstawie których budowano wystapienia. Po obradach prof. dr hab. Małgorza- 
ta Dajnowicz podsumowała spotkanie naukowe, podziękowała za wszystkie wystapienia oraz liczne głosy w dyskusji, które dowodziły dużego zainteresowania historią kobiet. Podkreśliła różnorodność zaprezentowanych źródeł i materiałów, a także interdyscyplinarne spojrzenie na całość tematyki, nie tylko $z$ punktu widzenia badaczy historii, ale również ze strony prasoznawców, politologów, socjologów oraz przedstawicieli nauk prawnych.

Kolejne spotkanie odbyło się w dniach 24 lipca -2 sierpnia 2020 r. w Augustowie i była to Białostocka Letnia Szkoła Historii Kobiet. Tematem przewodnim były badania historii kobiet w Polsce na przykładzie projektów badawczych indywidualnych i zespołowych. W szkole letniej udział wzięli młodzi badacze (doktoranci) wraz $z$ opiekunami naukowymi oraz doktorzy pracujacy nad rozprawami habilitacyjnymi. Uczestnicy reprezentowali różne ośrodki naukowe $z$ Polski, m.in. Uniwersytet $\mathrm{w}$ Białymstoku, Uniwersytet Marii Curie-Skłodowskiej w Lublinie, Uniwersytet Jana Kochanowskiego w Kielcach oraz Uniwersytet Pedagogiczny w Krakowie. Wśród grona specjalistów znaleźli się historycy, politolodzy, socjolodzy, prawnicy oraz medioznawcy prowadzacy badania zwiazane $z$ szeroko pojętą tematyką kobiecą.

Obrady merytoryczne zapoczatkowała prof. dr hab. Małgorzata Dajnowicz, witając gości oraz przedstawiając idee organizacji szkoły letniej. Jako pierwsza referat pt. Działalność Ligi Kobiet $w$ Małopolsce $w$ latach 1945-1957 zaprezentowała dr Maria Bauchrowicz-Tocka. Pozostając przy temacie Ligi Kobiet, jako następna wystapiła mgr Agnieszka Drozdowska, prezentując część swojej rozprawy doktorskiej, która koncentrowała się na działalności organizacji Ligi Kobiet na Białostocczyźnie w latach 1945-1989. Szczególną uwage w swoim wystapieniu zwróciła na przełomowe momenty $\mathrm{w}$ rozwoju organizacji kobiecej na ziemiach północno-wschodnich Polski Ludowej oraz metodologię i źródła, jakie wykorzystuje $\mathrm{w}$ swoich badaniach. Ponadto obie prelegentki przybliżyły historię organizacji oraz główne kierunki jej działalności, które koncentrowały się na pomocy potrzebującym kobietom, np. w postaci prowadzenia poradni rodzinnych i prawno-społecznych. Po obu wystapieniach podjęto dyskusję nad prezentowana tematyką, a także przeprowadzono indywidulne konsultacje nad prowadzonymi badaniami. Pierwszy dzień spotkania zakończyło omówienie przez prof. dr hab. Małgorzatę Dajnowicz celów działalności Ośrod- 
ka Badań Historii Kobiet. Pomysłodawczyni zaprezentowała poczynania Stowarzyszenia, funkcjonowanie "Czasopisma Naukowego Instytutu Studiów Kobiecych", a także zaznajomiła z celami projektu DIALOG finansowanego w ramach programu Ministra Nauki i Szkolnictwa Wyższego w latach 2019-2021.

W kolejnym dniu podjęto rozważania dotyczące czasopisma kobiecego „Zwierciadło”. Profesor dr hab. Małgorzata Dajnowicz przedstawiła obraz kobiety sukcesu na łamach „Zwierciadła”, pisma Ligi Kobiet Polskich w latach 1982-1989. Doktor Anna Szwed-Walczak zaś zaprezentowała referat pt. Obraz feminizmu na łamach polskiej prasy dla kobiet $w$ latach 1989-1992. Autorka wystapienia poddała analizie najpopularniejsze czasopisma przeznaczone dla kobiet w omawianym okresie, tj. „Przyjaciółkę”, „Kobietę i Życie”, „Zwierciadło”, „Filipinkę” oraz „Urodę”. Jako ostatnia tego dnia głos zabrała dr hab. prof. UP Magdalena Mikołajczyk, prezentując referat pt. Kontestatorki. Zaangażowanie opozycyjne (semiopozycyjne, quasi-opozycyjne) kobiet $w$ PRL po 1955 roku. Po każdym wystapieniu zadawano prelegentom pytania szczegółowe oraz udzielano wskazówek i uwag merytorycznych. Ponadto odbywały się indywidualne konsultacje profesorów $\mathrm{z}$ doktorantami, dyskutowano nad tematami badawczymi indywidualnymi i zbiorowymi. W czasie wolnym uczestnicy szkoły wzięli udział w programie kulturalnym zwiąanym z poznawaniem dziedzictwa kulturowego Pojezierza Augustowskiego i Suwalszczyzny.

W następnym dniu szkoły letniej wystapiła mgr Justyna Zajko-Czochańska, referując część badań podjętych w przygotowywanej pracy doktorskiej. Prezentacja dotyczyła roli tygodnika „Przyjaciółka” w życiu kobiet społeczności wiejskiej ze szczególnym uwzględnieniem edukacyjnej roli czasopisma w latach 1956-1975. Doktorantka przybliżyła historię najbardziej poczytnego czasopisma kobiecego okresu PRL, jego cech formalnowydawniczych, stosowanej metodologii wykorzystywanej do badań nad tygodnikiem oraz form upowszechniania wiedzy stosowanych przez redakcje periodyku. Doktor Diana Dajnowicz-Piesiecka skoncentrowała się natomiast na zaprezentowaniu ustawodawstwa dotyczacego rodziny i kobiet w Polsce Ludowej. Prelegentka przeanalizowała historię i rozwój aktów prawnych na rzecz ochrony praw kobiet. Po referatach przeprowadzono dyskusję, wniesiono uwagi oraz spostrzeżenia do podniesionych kwestii. W godzinach popołudniowych po 
zakończonych obradach i warsztatach została zorganizowana kolejna wizyta studyjna w obiektach dziedzictwa kulturowego okolic Augustowa. Podczas wizyty obejrzano miejsca historyczne istotne dla tego regionu Polski. Ponadto odwiedzono Studzieniczne Sanktuarium Maryjne związane $z$ objawieniami Matki Boskiej, które miały miejsce w XVIII w., a także $z$ wizyta w 1999 r. papieża Jana Pawła II podczas pielgrzymki do Polski.

Kolejny dzień spotkania poświęcony był prasie kobiecej okresu PRL. Doktor Łukasz Jędrzejski zaprezentował referat pt. Dyskurs polityczny $w$ Polskiej Rzeczypospolitej Ludowej na łamach tygodnika „Zwierciadło” w latach 1970-1980. Doktor Urszula Sokołowska zaś swoje wystapienie oparła na analizie pierwszego czasopisma adresowanego do nastolatek - „Filipince”. Prelegentka przybliżyła specyfikę pisma, odbiorców oraz podejmowaną tematykę, uwypuklając edukacyjna rolę periodyku w latach 1957-1989. Po każdym wystapieniu uczestnicy spotkania żywo dyskutowali nad zaprezentowana tematyką. Po zakończonej w tym dniu części merytorycznej w ramach programu kulturalnego udano się do Muzeum Ziemi Augustowskiej, gdzie poznano m.in. historię Kanału Augustowskiego - zabytku województwa podlaskiego będącego jednocześnie Pomnikiem Historii. Ponadto w muzeum zapoznano się $z$ dokumentem potwierdzającym prawa miejskie Augustowa $z$ podpisem króla Stanisława Augusta Poniatowskiego z 1792 r. oraz rękopisami Ignacego Prądzyńskiego $z$ lat 1823-1824.

W kolejnym dniu szkoły letniej jako pierwsza wystapiła prof. dr hab. Jolanta Chwastyk-Kowalczyk z referatem pt. „Prasowite zdziwienia" Katarzyny Bzowskiej-Budd - przedstawicielki polskiego dziennikarstwa fali emigracji „solidarnościowej”. Prelegentka zaprezentowała postać polskiej dziennikarki mieszkającej i pracującej w Londynie. Emigrantka lat 80., trwale wpisała się w pejzaż publicystyczny naszej diaspory, była redaktorką naczelną londyńskiego „Dziennika Polskiego i Dziennika Żołnierza”. Następnie wyniki swoich dociekań naukowych przedstawiały doktorantki mgr Agnieszka Śliwa oraz mgr Agnieszka Warzyńska. Pierwsza zaprezentowała wybrane przykłady prasy regionu kieleckiego w Polsce Ludowej, scharakteryzowała wybrane instytucje kultury, ze szczególnym uwzględnieniem instytucji zakładowych, a także przedstawiła czasopismo „Walczymy o Stal” oraz prezentowane w nim życie społeczne i kulturalne. Magister Agnieszka Warzyńska zaś skon- 
centrowała się na magazynach i analizie prasoznawczej gatunku prasowego na wybranych przykładach. Uzupełnieniem części merytorycznych spotkań było zaprezentowanie wydawnictwa Instytutu Studiów Kobiecych (Wydawnictwa HUMANICA) ze szczególnym uwzględnieniem „Czasopisma Naukowego Instytutu Studiów Kobiecych".

Po wszystkich wygłoszonych referatach, podjętych nad nimi dyskusjami, warsztatach oraz indywidualnych i grupowych konsultacjach organizatorka wydarzenia prof. dr hab. Małgorzata Dajnowicz podsumowała kilkudniowe obrady. Podziękowała wszystkim uczestnikom za udział oraz owocne spotkanie, zamykając tym samym pierwszą Białostocką Letnią Szkołę Historii Kobiet.

Kolejnym spotkaniem naukowym Ośrodka Badań Historii Kobiet była Ogólnopolska Konferencja Naukowa pt. Ruchy kobiece na ziemiach polskich $w$ XIX $i X X w$. Stań badań i perspektywy (na tle porównawczym) zorganizowana 11-14 września $2020 \mathrm{r.}^{2}$

23 października 2020 r. odbyło się IV Spotkanie Członków Zespołu i Współpracowników Ośrodka Badań Historii Kobiet Instytutu Studiów Kobiecych. Ze względu na sytuację epidemiologiczna wywołana COVID-19 spotkanie odbyło się $z$ udziałem ograniczonej liczby osób. Tematem przewodnim była Metodologia badan historii kobiet $i$ jej wykorzystywanie $w$ badaniach nauk humanistycznych (na przykładzie prasy dla kobiet). Wyniki prowadzonych badań $\mathrm{w}$ formie prezentacji i uwag merytorycznych do wystapień nadesłały badaczki z Uniwersytetu Jana Kochanowskiego w Kielcach. Profesor Olga Dąbrowska-Cendrowska przybliżyła zagadnienie dotyczace Prasy kobiecej w Polsce $w$ latach 1989-2020. Stan badan, metodologia - zarys problematyki, mgr Natalia Walkowiak przedstawiła opracowanie o tytule Prasa kobieca we Francji. Próba charakterystyki segmentu prasowego, mgr Weronika Sałek zaś - Miejsce kobiety $w$ brytyjskim magazynie "The Lady". W warsztatach, które przeprowadzono w Białymstoku, uczestniczyły prof. dr hab. Małgorzata Dajnowicz, mgr Agnieszka Drozdowska, mgr Justyna Zajko-Czochańska oraz mgr Justyna Granatowska. Warsztaty zostały poświęcone również indywidualnym konsultacjom dotycza-

2 Obszerne omówienie tej konferencji zob. Justyna Granatowska, „Sprawozdanie z Ogólnopolskiej Konferencji Naukowej "Ruchy kobiece na ziemiach polskich w XIX i XX w. Stan badań i perspektywy (na tle porównawczym) ", Białystok-Augustów 11-14 września 2020 r.”, s. 259 . 
cym aspektów badawczych $\mathrm{z}$ zakresu historii kobiet. W warsztatach wzięly udział badaczki zajmujące się historia kobiet.

12 grudnia 2020 r. odbyło się V Spotkanie Członków Zespołu i Współpracowników Ośrodka Badań Historii Kobiet. Tematem przewodnim były osiagnięcia naukowe Ośrodka Badań Historii Kobiet w latach 2019-2020. Wydarzenie miało zatem charakter podsumowujący dotychczasowe prace badawcze członków stałych oraz współpracowników Ośrodka. Jednocześnie podczas obrad, które ze względu na obecną sytuacją epidemiologiczna przybrały w części formę spotkania online, przedstawiono perspektywy i plany badawcze na kolejny rok 2021.

Spotkanie rozpoczęto powitaniem uczestników przez kierownik zespołu badawczego oraz prezes Stowarzyszenia Instytutu Studiów Kobiecych - prof. dr hab. Małgorzatę Dajnowicz. Inicjatorka wydarzenia wyraziła ogromną radość z możliwości spotkania $z$ większością członków Ośrodka i osób współpracujących z OBHK. Zaznaczyła, że biorąc pod uwage specyfikę trudności w mijającym roku 2020, jest zadowolona $z$ efektów prac nad historia kobiet pod egida OBHK, rozwoju badań nad tematyka kobieca oraz prac naukowych wykonanych przez wszystkich członków zespołu. Spotkanie składało się $z$ trzech części. Po poszczególnych wystapieniach prelegentów przewidziany był czas na zadawanie pytań oraz dyskusję nad przedstawionym tematem.

Pierwsza część obrad rozpoczał referat prof. dr hab. Agnieszki Szudarek pt. Skazane na rywalizacje. Relacje między polskim a niemieckim ruchem kobiecym w Poznaniu na poczatku XX wieku. Prelegentka podsumowała swoje ustalenia naukowe oscylujace wokół niemieckiego ruchu kobiecego oraz aktywności Polek i Niemek w Poznaniu. Podkreśliła ogromny wkład kobiet w pracę społeczna oraz rolę prasy jako łącznika kulturowego między społecznościa polską i niemiecka. Jako druga wystapiła prof. dr hab. Ewa Maj z referatem pt. Narodowa prasa dla kobiet $w$ Polsce międzywojennej: realizacja tematu i wyzwania badawcze. Ukazała szeroki wachlarz zagadnień związanych $z$ prasa, której problematyka ściśle wiąała się $z$ pojęciem narodu jako naczelnym elementem funkcjonowania społeczeństwa. W kolejnym referacie pt. Londyńskie $i$ krajowe inspiracje prof. dr hab. Jolanta Chwastyk-Kowalczyk przybliżyła członkom i współpracownikom Ośrodka działalność polskich dziennikarzy na londyńskiej emigracji. Opisała również trudy życia codziennego pol- 
skiego środowiska dziennikarskiego publikującego w Londynie. Jako ostatnia przed przerwa wystapiła mgr Justyna Zajko-Czochańska, która zaprezentowała koncepcję swojej rozprawy doktorskiej pt. Edukacyjna rola „Przyjaciółki” w życiu kobiet wiejskich Polskiej Rzeczpospolitej Ludowej w latach 1956-1975. Doktorantka przedstawiła plan ramowy pracy doktorskiej, skupiając się na omówieniu zawartości poszczególnych rozdziałów, dotyczących m.in. cech formalnowydawniczych „Przyjaciółki”, funkcjonowania kobiet na wsiach oraz ich działalności, np. w kołach gospodyń wiejskich. Zwróciła również uwage na rolę edukacyjna czasopisma, przejawiająca się w upowszechnianiu określonych postaw i zachowań ludności wiejskiej.

Po przerwie wznowiono watek rozpraw doktorskich powstających pod kierunkiem prof. Małgorzaty Dajnowicz. Magister Agnieszka Zaniewska przygotowująca dysertację pt. Liga Kobiet na Białostocczyźnie zaprezentowała cele i założenia badawcze swojej pracy. Wśród nich znalazły się takie zagadnienia, jak działalność Ligi Kobiet na Białostocczyźnie w latach 1945-1989 na tle ówczesnej sytuacji $\mathrm{w}$ kraju $\mathrm{w}$ porównaniu $\mathrm{z}$ działalnością organizacji $\mathrm{w}$ innych województwach. Ponadto doktorantka omówiła zasoby źródłowe, na podstawie których powstaje jej rozprawa.

Tematykę Ligi Kobiet kontynuowała prof. dr hab. Małgorzata Dajnowicz w wystapieniu pt. Liga Kobiet - polska organizacja kobieca $w$ latach 1945-1989. Prelegentka obszernie zreferowała dotychczasowe ustalenia badawcze, m.in. liczne kwerendy w łódzkich archiwach Ligi Kobiet. Ukazała cele programowe organizacji w poszczególnych okresach. Podkreśliła wszechstronne działanie Ligi Kobiet, której prace związane były m.in. $z$ walką o pokój na świecie, staraniami na rzecz zmniejszenia analfabetyzmu, aktywizacja zawodowa kobiet, upowszechnianiem praw kobiet i dzieci oraz promocją określonych postaw społecznych wśród kobiet.

Jako kolejny głos zabrał dr Łukasz Jędrzejski. W swoim referacie pt. Dyskurs polityczny $w$ prasie dla kobiet (1944-1988) omówił wyzwania i postulaty badawcze związane $z$ watkami politycznymi podejmowanymi przez redakcje periodyków kobiecych po drugiej wojnie światowej. Zaznaczył różnorodność poruszanej problematyki oraz wpływ ówczesnej sytuacji polityczno-gospodarczej na zawartość poszczególnych czasopism adresowanych do kobiet.

Druga część obrad zamknęło wystapienie dr Urszuli Sokołowskiej pt. Poradnictwo na łamach „Filipinki”. Członkini zespołu 
badawczego zaprezentowała swoje ustalenia naukowe zwiąane $z$ analiza zawartości kolejnych wydań „Filipinki”. Skupiła się na wątku szeroko rozwiniętego poradnictwa oraz sposobie, w jaki redakcja periodyku starała się upowszechniać zasady życia społecznego wśród młodych kobiet w PRL.

Ostatnią część obrad zainaugurowało wystapienie dr Marii Bauchrowicz-Tockiej pt. Posłanki - liderki Ligi Kobiet (na wybranym przykładzie). Prelegentka przedstawiła postać Marii Jaszczuk, prawniczki i posłanki, jednej z liderek Ligi Kobiet. Opisywana kobieta miała nieoceniony wkład w życie polityczne oraz społeczne. Angażowała się w sprawy uchodzące ówcześnie za najważniejsze dla kobiet, m.in. kwestie świadomego macierzyństwa oraz prace nad wdrożeniem ustawy o możliwości przerywania ciąży w PRL.

Następnie referat pt. Kwestia kobieca w Polskiej Kronice Filmowej (postulaty badawcze) wygłosiła mgr Justyna Granatowska. Absolwentka Uniwersytetu w Białymstoku zaprezentowała wstępny zarys rozprawy doktorskiej, nad która pracę zamierza podjąć w najbliższym czasie.

Jako kolejna głos zabrała dr Anna Szwed-Walczak. Jej referat pt. Polityczność polskiej prasy dla kobiet w latach 1989-1992 - potencjal $i$ perspektywy badań był swoistym podsumowaniem ustaleń naukowych badaczki. Autorka wystapienia szeroko omówiła zagadnienia polityczne poruszane przez redakcje najbardziej popularnych periodyków dla kobiet okresu PRL, m.in. „Przyjaciółki”, „Kobiety i Życia” oraz „Zwierciadła”. Przedstawiła szereg wątków związanych z politycznościa polskiej prasy, jak chociażby działalność organizacji kobiecych czy aktywność polityczna kobiet, które znalazły odzwierciedlenie na łamach czasopism kobiecych u schyłku PRL. Jednocześnie wyraziła głębokie przekonanie o nieodkrytym jeszcze potencjale badawczym, jaki skrywaja periodyki kobiece wydawane w okresie transformacji systemowej 1989-1992.

Ostatni referat wygłosiła prof. dr hab. Magdalena Mikołajczyk. Wystapienie pt. Kontestatorki, opozycjonistki, uczestniczki społecznych protestów $w$ polskiej biografistyce, historiografii i naukach społecznych opisywało działalność polskich kobiet aktywnych $\mathrm{w}$ ruchach politycznych $\mathrm{i}$ organizacjach antysystemowych w PRL. Prelegentka postawiła trzy pytania o obecność polityczna kobiet, wokół których koncentrowała swoje dotychczasowe badania 
naukowe. Przedstawiła także życiorysy kobiet działających w opozycji antykomunistycznej.

Obrady zakończyła merytoryczna dyskusja podsumowująca V Spotkanie Członków Zespołu i Współpracowników Ośrodka Badań Historii Kobiet. Inicjatorka niniejszych obrad - prof. zw. dr hab. Małgorzata Dajnowicz podziękowała wszystkim uczestnikom za obecność i wkład włożony w rozwój badań realizowanych w Ośrodku. Podkreśliła, iż pomimo trudnego 2020 r. udało się ustalić wiele nowych wątków dotyczących historii kobiet, zwłaszcza XIX i XX w. Zwróciła także uwagę na różne pola aktywności i tematykę oraz różnorodność metod, źródeł i materiałów badawczych wykorzystywanych przez uczestników spotkania. Profesor Dajnowicz zaznaczyła, że dotychczasowe ustalenia znalazły swoje odzwierciedlenie w publikacjach naukowych, m.in. w „Czasopiśmie Naukowym Instytutu Studiów Kobiecych", publikacji pokonferencyjnej, w materiałach prezentowanych $\mathrm{w}$ mediach (TVP, radio), portalach społecznościowych, debatach pozaakademickich, dydaktyce. Tematyka historii kobiet wymaga również kontynuacji w postaci planowanych artykułów, monografii książkowych. Wyraziła też satysfakcję $z$ powodu przenoszenia ustaleń poczynionych w ramach działalności Ośrodka właśnie na grunt dydaktyczny, co znajduje odzwierciedlenie w wykładach, konwersatoriach, w powstających kolejnych pracach dyplomowych dotyczacych historii kobiet.

Warto $z$ naciskiem podkreślić, że efektem intensywnych badań, konferencji, konsultacji, warsztatów, debat tematycznych sa publikacje naukowe zamieszczane przede wszystkim w "Czasopiśmie Naukowym Instytutu Studiów Kobiecych”. Ponadto upowszechnianie wyników badań Ośrodka odbywa się poprzez emisję licznych materiałów telewizyjnych czy audycji radiowych. 